\section{J I T A A}

Journal of the Indonesian Tropical Animal Agriculture Accredited by Ditjen Penguatan Risbang No.60/E/KPT/2016
J. Indonesian Trop. Anim. Agric. pISSN 2087-8273 eISSN 2460-6278 http://ejournal.undip.ac.id/index.php/jitaa 46(4):325-335, December 2021

\title{
Application of green tea waste with fibrolytic enzyme and phytase on layer performance and egg quality
}

\author{
S. Chumkam ${ }^{1 *}$, O. Jintasataporn ${ }^{2}$ and S. Triwutanon ${ }^{3}$ \\ ${ }^{1}$ Faculty of Agricultural Technology, Valaya Alongkorn Rajabhat University \\ under the Royal Patronage, PathumThani, 13180, Thailand. \\ ${ }^{2}$ Department of Aquaculture, Faculty of Fisheries, Kasetsart University, \\ Bangkok, 10900, Thailand \\ ${ }^{3}$ Department of Large Animal and Wildife Clinical Sciences, Faculty of Vaterinary Medicine \\ Kasetsart University, Kamphaeng Saen, Nakhon Pathom 73140, Thailand \\ *CorrespondingE-mail : srinoy@vru.ac.th
}

Received June 01, 2020; Accepted June 13, 2021

\begin{abstract}
ABSTRAK
Penelitian ini bertujuan untuk mengetahui pengaruh suplementasi limbah teh hijau, enzim fibrolitik (xilanase dan selulase) dan fitase pada ransum petelur terhadap performans dan kualitas telur. Percobaan ditugaskan dalam pengaturan faktorial $2 \times 3$ dengan desain acak lengkap. Faktor A terdiri dari dua jenis diet: a) diet basal tanpa limbah teh hijau dan b) diet basal dengan $1 \%$ limbah teh hijau. Faktor B terdiri dari tiga level enzim: a) level 0X, tanpa suplementasi enzim; b) level 1X, kombinasi enzim fibrolitik, 24.000 FAXU xilanase dan 100 ECU selulase, dan 1.000 FTU fitase; dan c) level 2X, kombinasi enzim fibrolitik, 48.000 FAXU xilanase dan 200 ECU selulase, dan 2.000 FTU fitase. Seratus sembilan puluh dua ekor ayam ras Roman Brown, umur 52 minggu, dibagi secara acak ke dalam enam kelompok dan empat ulangan. Ayam petelur diberi makan makanan komersial dengan limbah teh hijau dan enzim fibrolitik ditambahkan di atas seperti yang ditugaskan dalam pengobatan. Hasil penelitian menunjukkan bahwa limbah teh hijau meningkatkan produksi telur, massa telur, konversi pakan, dan Haugh unit secara nyata $(\mathrm{p}<0,05)$. Selain itu, limbah teh hijau cenderung mempengaruhi $(\mathrm{p}=0,07)$ nilai TBA. Selanjutnya, tingkat enzim menurun secara signifikan $(\mathrm{p}<0,05)$ asupan pakan dan nilai TBA. Suplementasi 1\% limbah teh hijau dan enzim 2X dapat meningkatkan konversi pakan dan sifat antioksidan telur.
\end{abstract}

Kata kunci: Ampas teh hijau, Xylanase, Selulase, Fitase, Kinerja ayam petelur.

\begin{abstract}
This study aimed to investigate the effect of green tea waste, fibrolytic enzymes (xylanase and cellulase) and phytase supplementation in layer diets on performance and egg quality. The experiment was assigned in a $2 \times 3$ factorial arrangement by completely randomized design. Factor A consisted of two types of diets: a) a basal diet without any green tea waste and b) a basal diet with $1 \%$ of green tea waste. Factor B consisted of three levels of enzymes: a) level 0X, no enzyme supplementa-
\end{abstract}


tion; b) level 1X, a combination of fibrolytic enzymes, 24,000 FAXU xylanase and 100 ECU cellulase, and 1,000 FTU phytase; and c) level 2X, combination of fibrolytic enzymes, 48,000 FAXU xylanase and 200 ECU cellulase, and 2,000 FTU phytase. One hundred and ninety- two Roman Brown hens, aged 52 weeks, were randomly distributed to six groups and four replications. Layer hens were fed commercial diets with green tea waste and fibrolytic enzymes added on top as assigned in the treatment. The results showed that green tea waste significantly increased $(p<0.05)$ egg production, egg mass, feed conversion, and Haugh unit. In addition, green tea waste tended to affect $(p=0.07)$ TBAs value. Furthermore, the enzyme level significantly decreased $(p<0.05)$ feed intake and TBAs value. In conclusion, the supplementation of $1 \%$ of green tea waste and $2 X$ enzymes can improve feed conversion and the antioxidative property of eggs.

Keywords: Green tea waste, Xylanase, Cellulase, Phytase, Layer performance.

\section{INTRODUCTION}

Green tea waste is a by-product from the tea beverage industry. In waste management, some kinds of tea wastes are used in composting materials but most of them are disposed as industrial waste. In the long run, it can cause environmental pollution.

Green Tea (Camellia sinensis), a kind of herb, contains proteins, amino acids, carbohydrates, vitamins, minerals and polyphenols, such as catechins, tannin, etc. Polyphenols have antioxidant properties to reduce oxidation in the animal body which causes cancer and inflammation (Yamamoto et al., 1997; Miyazawa, 2000; Trompezinski et al., 2003). In addition, tannin in tea also has antibacterial activities that reduce a large number of bacteria ( $\mathrm{Li}$ and Liu, 1999). Considered as a by-product, green tea waste may have potential as animal feed after it has been through the beverage production process since it still contains proteins, carbohydrates, and phenol compounds ( Tsubaki et al., 2008; Toh et al., 2010). The chemical compositions of green tea waste contain $22-35 \%$ of crude protein, 19.5 $62.03 \%$ of crude fiber, $29.9-31.0 \%$ of Neutral Detergent Fiber (NDF), 22.4-24.1\% of Acid Detergent Fiber (ADF) , 11.39\% of phenolics, 5.95 $-9.23 \%$ of tannins (Yang et al., 2003; Kondo et al., 2004a, b; Nishida et al., 2006 ), and 9.18\% of DPPH scavenging activity (IC50) (Bunyapraphatsara and Prapinsara, 2007). Previous studies suggest that green tea waste could be used as a source of antioxidants or nutrients in animal feed for broilers and laying hens (Yang, 2003a, b), pigs (Ko et al., 2008), cows (Kendo et al., 2004b) and cattle (Nishida et al., 2006). However, tea has a high level of fiber, which consists of celluloses, hemicelluloses, pectin and oligosaccharides, etc. Poultry does not have enzymes for digesting insoluble polysaccharides especially non starch polysaccharides such as celluloses, hemicelluloses, pectin and it also lacks endogenous phytase. Therefore, supplementation of fibrolytic enzymes in chicken diet can improve the digestibility and feed efficiency (Yu et al., 2004; Khattak et al., 2006). The final product of fibrolytic enzyme digestion is sugar, which is the source of energy for animals. (Bedford, 2000; Woyengo et al. 2011). There are many fibrolytic enzymes used in animal feeds, such as cellulase, xylanase and hemicellulase, which are produced by various microorganisms. The digestibility efficiency of each enzyme is different, so it must be applied appropriately. In addition, plants have phytate bound to some minerals, sugar and amino acids. Phytate decreases the digestion and utilization of nutrients. Phytase supplementation can increase the digestibility of other minerals, amino acids and energy, which are bound to phytic acid (Ravindran et al., 2001; Ravindran et al., 2006). The objectives of this experiment was to investigate the effect of fibrolytic enzymes and phytase enzyme supplementation in green tea waste diets on layer performance and egg quality, which helps add the value of green tea waste from the tea beverage industry and keep waste to the minimum.

\section{MATERIALS AND METHODS}

\section{Green Tea Waste}

Green tea waste (GTW) from the green tea beverage industry (in Phra Nakhon Si Ayutthaya province, Thailand) was dried at $60{ }^{\circ} \mathrm{C}$ for 6-8 hr. and ground to powder. The chemical compositions of GTW were analyzed according to AOAC (1990) included $16.62 \%$ of crude proteins, $2.06 \%$ of crude lipids, $37.77 \%$ of crude 
fibers and $4841.80 \mathrm{Kcal}$ of gross energy There were also $0.01 \%$ of tannin analyzed by the $\mathrm{FAO} /$ IAEA method (2000), $56.56 \%$ of DPPH scavenging analyzed by the method of Roche et al. (2005), and $203.43 \mathrm{mg} . / \mathrm{kg}$. of carotenoid analyzed by the method of Foss et al. (1984). The green tea waste's nutritive values and active compounds were investigated at the Nutrition and Aquafeed Laboratory, Department of Aquaculture, Faculty of Fisheries, Kasetsart University, Bangkok, Thailand.

\section{Enzyme}

A combination of two types of enzymes in liquid form (AB Vista Asia Pte. Ltd., Singapore), fibrolytic enzymes (xylanase and cellulase) and phytase enzyme were used in this study. The application of these enzymes for chickens were level 1X fibrolytic enzymes equal to 24,000 FAXU xylanase and 100 ECU cellulase, level $1 \mathrm{X}$ phytase equal to $1,000 \mathrm{FTU}$ and level $2 \mathrm{X}$ fibrolytic enzymes equal to 48,000 FAXU xylanase and 200 ECU cellulase, level 2X phytase equal to 2,000 FTU. One unit of FAXU equals to one unit of xylanase activities as analyzed by the ABvista in-house method. One unit of ECU equals to one unit of cellulase activities as analyzed by the ABvista in-house method.

\section{Experimental Diet}

The experimental diet was commercial diet composed of corn, soybean and other raw materials (from Laemthong Corporation Company) which consisted of $18.12 \%$ of crude protein, $4.69 \%$ of crude fat, $12.79 \%$ of crude fiber and $3751.14 \mathrm{Kcal}$ of gross energy (Table 1). All supplementations in the diet like GTW and a combination of fibrolytic enzymes and phytase were added on top of the feed.

\section{Animal: Layer Hens}

One hundred and ninety two Roman Brown hens purchased from a layer hen farm in Nakornnayok province was quarantined in the farm of Agricultural Technology Faculty, Valaya Alongkorn Rajabhat University, under the Royal Patronage, Pathum Thani province. Layer hens were stocked in a trail condition and fed a control diet including vitamins in water for 14 days before the experiment began.

\section{Experimental Design}

The experiment was assigned in a $2 \times 3$ factorial arrangement by completely randomized design. Factor A consisted of two types of diets: a) a basal diet without any green tea waste (GTW0) and b) a basal diet with $1 \%$ of green tea waste (GTW1). Factor B consisted of three levels of enzymes: a) level $0 \mathrm{X}$, no enzyme supplementation (E0); b) level 1X, a combination of fibrolytic enzymes, 24,000 FAXU xylanase and 100 ECU cellulase, and 1,000 FTU phytase (E1); and c) level $2 \mathrm{X}$, a combination of fibrolytic enzymes, 48,000 FAXU xylanase and 200 ECU cellulase, and 2,000 FTU phytase (E2).

The research was divided into six groups; each group contained 4 replicates, with 8 hens (aged 52 weeks) in each replicate. The experimental diets were as follows: T1, a basal diet without any green tea waste and enzyme $0 \mathrm{X}$ (GTW0E0); T2, a basal diet that contained 1X enzymes (GTW0E1); T3, a basal diet that contained 2X enzymes (GTW0E2); T4, a basal diet that contained $1 \%$ of GTW without enzyme (GTW1E0); T5, a basal diet that contained 1\% of GTW and 1X enzymes (GTW1E1); and T6, a basal diet that contained $1 \%$ of GTW and $2 \mathrm{X}$ enzymes (GTW1E2). The GTW and a combination of fibrolytic enzyme and phytase supple-

Table 1. Enzyme activity of experimental diets

\begin{tabular}{lllccc}
\hline $\begin{array}{l}\text { Green tea } \\
\text { waste (\%) }\end{array}$ & $\begin{array}{c}\text { Enzyme } \\
\text { level }\end{array}$ & Treatment & $\begin{array}{c}\text { Phytase } \\
\text { Activity } \\
\text { (FTU/kg) }\end{array}$ & $\begin{array}{c}\text { Xylanase } \\
\text { Activity } \\
(\text { FAXU/kg) }\end{array}$ & $\begin{array}{c}\text { Cellulase } \\
\text { Activity } \\
\text { (ECU/kg) }\end{array}$ \\
\hline \multirow{2}{*}{ GTW0 } & E0 & GTW0E0 & 312 & 12000 & 2700 \\
& E1 & GTW0E1 & 1410 & 38100 & 2400 \\
& E2 & GTW0E2 & 2260 & 57500 & 2300 \\
\hline \multirow{3}{*}{ GTW1 } & E0 & GTW1E0 & 359 & 13900 & 2100 \\
& E1 & GTW1E1 & 1200 & 38100 & 2000 \\
& E2 & GTW1E2 & 2070 & 61000 & 3200 \\
\hline
\end{tabular}

GTW $=$ Green tea waste; $\mathrm{E}=$ Enzyme; GTW0 $=$ Non supplementation with green tea waste; GTW1 = Supplementation with green waste $1 \%$; E0 = Non supplementation with enzyme; E1 = Supplementation with enzyme 1X; E2 = Supplementation with enzyme 2X 
mentation was added on top of the feed.

\section{Experimental Condition}

The Layer hens were reared in the evaporated housing at temperature $28 \pm 1{ }^{\circ} \mathrm{C}$, and supplied with drinking water as well as $16 \mathrm{hr}$. daylight intensity. The experimental diet were distributed ad libitum to the hens in mash form and topped up with GTW and enzyme. The trial period was 84 days.

\section{Data Collection}

The study was divided into three periods of 28 days, including data collection and the calculation of variables of performance and egg quality. The layer performance was observed in terms of feed intake $(\mathrm{g} / \mathrm{h} / \mathrm{d})$, egg production $(\%)$, egg weight (g), egg mass (g), and feed conversion (feed consumption per kilogram of eggs). Six eggs per replication (24 eggs /treatment) were collected randomly during the last three days of each period. Egg quality was evaluated in terms of egg weight, yolk color by using a yolk color fan (Roche, Switzerland), Haugh unit by using height gauge (TSS-QCD instrument, England), egg shell thickness by taking measurement using micrometer (395-541-30 BMD-25DM, Mitutoya, Japan), specific egg gravity by immersing the eggs in salt solutions of specific gravities and counting the number of floating and sinking eggs, and thiobarbituric acid reactive substance values (TBAs) by using the method of Cherian et al. (1996) and Botsoglou et al. (1994).

\section{Enzyme Activity}

Enzyme activity of the experimental diets was analyzed by the ABvista in- house method. The enzyme phytase was conducted on Quantum Blue in-feed (wet chemistry method); the enzyme xylanase was determined on Econase XT; the enzyme cellulase was analyzed on Vista Pre-T (wet chemistry method) (the ABvista in-house method, 2018). (Table1)

\section{Efficacy of Exogenous Enzyme Supplementa- tion}

The efficacy of exogenous enzyme supplementation on experimental diets was studied by in vitro digestibility of the experimental diets, following the modified method of Bisswanger (2011). The fine ground diet was incubated in the buffer $(\mathrm{pH} \mathrm{6.5)}$ for 6 hours. Then the reaction was stopped by immerging the diet in water bath at $100{ }^{\circ} \mathrm{C}$ for 5 minutes. The reducing sugar in term of glucose was determined for carbohydrate digestion products by dinitrosalicylic acid (DNS). The amino acid content was determined by ninhydrin and the soluble protein content was determined by biuret test for the protein digestion products. The amount of phosphate was determined by an assay mixture for phosphorus digestion products. All enzyme assays and in vitro digestibility were studied at the Nutrition and Aquafeed Laboratory, Department of Aquaculture, Faculty of Fisheries, Kasetsart University, Bangkok, Thailand.

\section{Statistical Analysis}

The data of this research were analyzed by analysis of variance. Duncan's New Multiple Range test was used to compare the mean difference The alphabetical notation was applied to determine differences at the $95 \%$ confidence interval (alpha 0.05).

\section{RESULTS AND DISCUSSION}

\section{Efficacy of Exogenous Enzyme Supplemen- tation in Layer Diets}

The efficacy of exogenous enzyme supplementation on the experimental diet digestibility is detailed in Table 2. The reducing sugar presented the efficacy of fibrolytic enzymes for improving carbohydrate digestion. The phosphate demonstrated the efficacy of phytase enzyme for improving phytate digestion. The amino acid and soluble protein exhibited the efficacy of both enzymes for improving protein digestion. The results showed that the supplementation of GTW in layer diets (GTW1E0, GTW1E1 and GTW1E2) exhibited poor $(p<0.05)$ carbohydrate, amino acids and phosphorus digestibility compared to the basal diet without GTW (GTW0E0, GTW0E1 and GTW0E2). The supplementation of phytase, cellulase and xylanase enzyme in diet without GTW (GTW0E1 and GTW0E2) showed significantly higher level of phosphorus $(\mathrm{p}<0.05)$, carbohydrate and protein digestion in terms of amino acids higher $(\mathrm{p}<0.05)$ than the diets with GTW supplementation. Moreover, the layer diets with GTW supplementation (GTW1E0, GTW1E1 and GTW1E2) showed no significant differences $(p>0.05)$ on phosphorus and protein digestion.

Woyengo et al. (2011) reported that fibrolytic enzymes were effective in releasing reducing sugar, amino acids and other nutrients 
Table2. Efficacy of exogenous enzyme supplementation in layer diets

\begin{tabular}{|c|c|c|c|c|c|c|}
\hline $\begin{array}{l}\text { Green tea } \\
\text { waste }(\%)\end{array}$ & $\begin{array}{c}\text { Enzyme } \\
\text { level }\end{array}$ & Treatment & $\begin{array}{l}\text { Amino acid } \\
\qquad(\mathrm{g} / \mathrm{kg})\end{array}$ & $\begin{array}{l}\text { Protein } \\
(\mathrm{g} / \mathrm{kg})\end{array}$ & $\begin{array}{c}\text { Reducing } \\
\text { sugar } \\
(\mathrm{g} / \mathrm{kg}) \\
\end{array}$ & $\begin{array}{l}\text { Phosphorus } \\
\text { (g/kg) }\end{array}$ \\
\hline \multirow{6}{*}{ GTW0 } & \multirow[t]{2}{*}{ E0 } & \multirow[t]{2}{*}{ GTW0E0 } & $0.629^{b}$ & 0.274 & $2.783^{\mathrm{a}}$ & $0.003^{\mathrm{a}}$ \\
\hline & & & \pm 0.01 & \pm 0.03 & \pm 0.18 & \pm 0.001 \\
\hline & \multirow[t]{2}{*}{ E1 } & \multirow[t]{2}{*}{ GTW0E1 } & $0.650^{\mathrm{b}}$ & 0.297 & $2.333^{\mathrm{a}}$ & $0.004^{\mathrm{a}}$ \\
\hline & & & \pm 0.04 & \pm+0.06 & \pm 0.22 & \pm 0.001 \\
\hline & \multirow[t]{2}{*}{ E2 } & \multirow[t]{2}{*}{ GTW0E2 } & $0.733^{\mathrm{a}}$ & 0.321 & $1.983^{\mathrm{b}}$ & $0.003^{\mathrm{a}}$ \\
\hline & & & \pm 0.05 & \pm 0.04 & \pm 0.57 & \pm 0.001 \\
\hline \multirow{6}{*}{ GTW1 } & \multirow[t]{2}{*}{ E0 } & \multirow[t]{2}{*}{ GTW1E0 } & $0.517^{\mathrm{c}}$ & 0.251 & $1.090^{\mathrm{c}}$ & $0.001^{b}$ \\
\hline & & & \pm 0.02 & \pm 0.03 & \pm 0.07 & \pm 0.0003 \\
\hline & \multirow[t]{2}{*}{ E1 } & \multirow[t]{2}{*}{ GTW1E1 } & $0.530^{\mathrm{c}}$ & 0.292 & $1.299^{\mathrm{c}}$ & $0.002^{\mathrm{b}}$ \\
\hline & & & \pm 0.03 & \pm 0.04 & \pm 0.07 & \pm 0.0002 \\
\hline & \multirow[t]{2}{*}{ E2 } & \multirow[t]{2}{*}{ GTW1E2 } & $0.556^{\mathrm{c}}$ & 0.326 & $1.345^{\mathrm{c}}$ & $0.002^{\mathrm{b}}$ \\
\hline & & & \pm 0.06 & \pm 0.09 & \pm 0.01 & \pm 0.0001 \\
\hline \multirow{3}{*}{ P-value } & \multicolumn{2}{|l|}{$\mathrm{E}$} & 0.0153 & 0.1560 & 0.0315 & 0.6233 \\
\hline & \multicolumn{2}{|l|}{ GTW } & 0.0001 & 0.7512 & 0.0001 & 0.0001 \\
\hline & \multicolumn{2}{|l|}{ E x GTW } & 0.2929 & 0.8836 & 0.0030 & 0.0594 \\
\hline
\end{tabular}

Mean values within the same column with difference superscripts are significantly different $(\mathrm{P}<0.05)$.

Data are expressed with mean \pm SD. GTW $=$ Green tea waste; $\mathrm{E}=$ Enzyme; GTW0 $=$ Non supplementation with green tea waste; GTW1 = Supplementation with green waste $1 \%$; E0 $=$ Non supplementation with enzyme; E1 = Supplementation with enzyme $1 \mathrm{X} ; \mathrm{E} 2$ = Supplementation with enzyme $2 \mathrm{X}$

by means of hydrolyzing non starch polysaccharides in plant cell walls. In addition, carbohydrase can also increase the efficacy of phytase by increasing the accessibility of phytase to phytic acid and absorption of nutrients released by phytase. Phytase supplementation can increase the digestibility of other minerals, amino acids and energy which are bound with phytic acid (Ravindran et al., 2001; Ravindran et al., 2006). The highest amino acid digestibility in the GTW0E2 group showed the synergism between supplemental fibrolytic enzymes (xylanase and cellulase) and phytase on amino acid utilization. The reducing sugar presented the efficacy of fibrolytic enzymes on fiber digestion to release sugar as energy for animals (Bedford, 2000). In the diets without GTW that contained $12.79 \%$ of fiber, supplemental fibrolytic enzyme or carbohydrase and phytase seemed to have a low impact on carbohydrate digestibility due to GTW0E0 and GTW0E1 groups had the same reducing sugar level. However, the GTW0E2 group had a lower level of sugar when compared to GTW0E0 and GTW0E1 groups, although this group of diets was supplemented with a high level of enzymes. These may come from a wide range of standard deviation $(1.983 \pm 0.57 \mathrm{~g} . / \mathrm{kg}$.) compared to GTW0E0
$(2.783 \pm 0.18 \mathrm{~g} . / \mathrm{kg}$.$) and GTW0E1 (2.333 \pm 0.22$ g./ $\mathrm{kg}$.). The in vitro phosphorus digestibility in the basal diets without GTW (GTW0E0, GTW0E1 and GTW0E2) both with and without phytase enzymes demonstrated a significantly higher efficacy $(p<0.05)$ than GTW diets (GTW1E0, GTW1E1 and GTW1E2). The phytase enzyme worked on phytate digestibility and liberated more phosphorus (Woyengo et al, 2011). GTW decreased amino acid, carbohydrate and phosphorus digestibility in GTW1E0, GTW1E1 and GTW1E2, due to the anti-nutritional compound of GTW. The present study revealed that GTW containted $0.01 \%$ of tannin. Tannin is a complex group of polyphenolic compounds. They are naturally- occurring plant polyphenols that combine with protein and other polymers such as cellulose, hemicellulose and pectin to form stable complexes (Mangan, 1988; Krueger et al, 2010), and reduced the digestibility of protein and carbohydrate like starch and cell wall particularly in protein digestion (Mueller-Harvey, 2006; Bravo ,1998; Jansman, 1993). Supplementation of fibrolytic enzymes and phytase in GTW diets did not improve the digestibility of nutrients as much as diets without GTW. However, enzyme supplementation in the GTW1E0, GTW1E1 and GTW1E2 groups enhanced the nutritional di- 

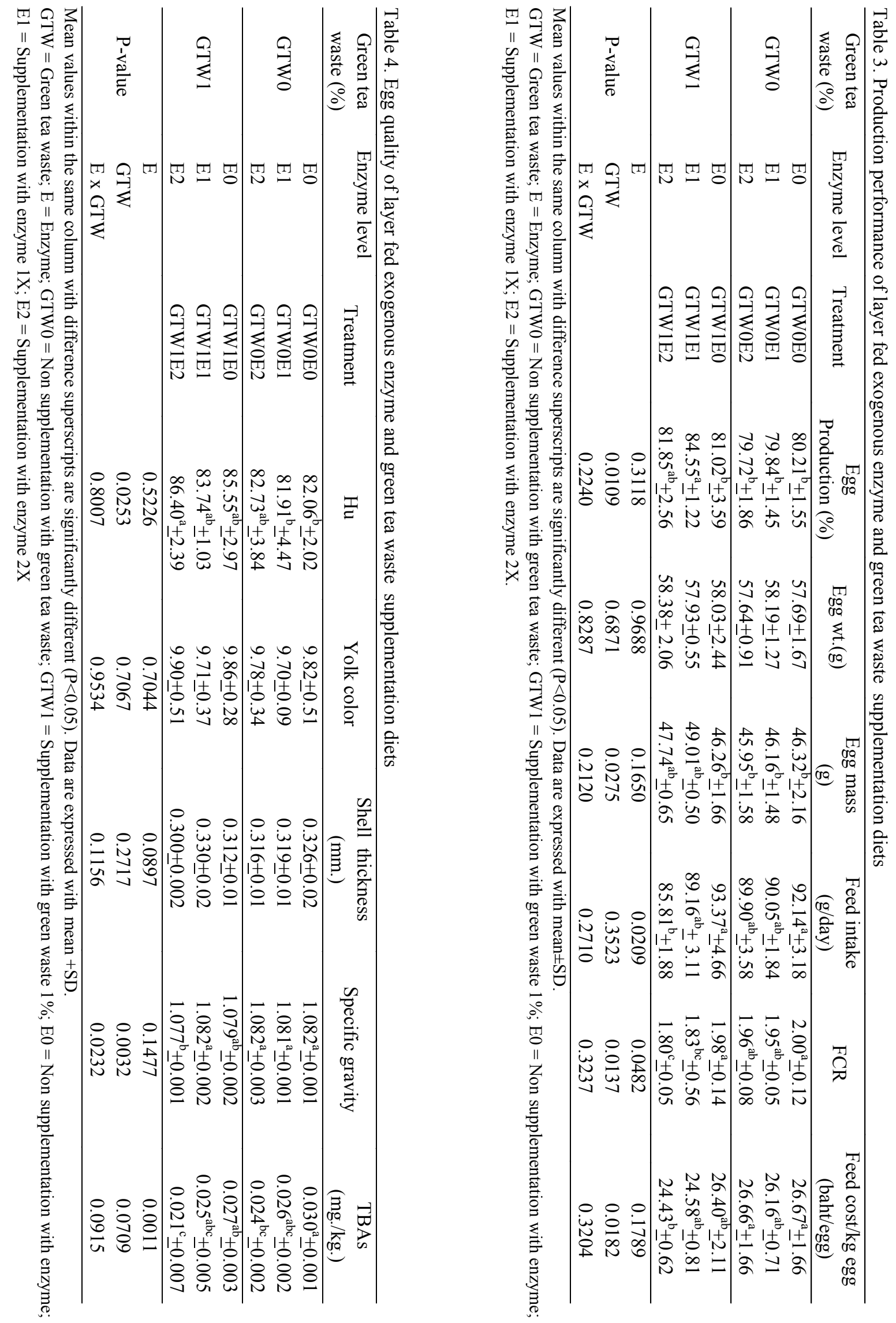
gestibility of layer diets.

\section{Egg Production Performance}

Egg production performance is detailed in Table 3. There was no interaction effect on egg production performance. Egg production, egg weight, egg mass and feed cost $/ \mathrm{kg}$ of eggs were not significantly influenced by the enzymes but green tea waste had an effect on egg production, egg mass, feed conversion and feed cost $/ \mathrm{kg}$ of eggs $(p<0.05)$. A high rate of egg production and egg mass were observed in the GTW1E1 group, followed by the GTW1E2 group. Feed cost $/ \mathrm{kg}$ of eggs was significantly low $(p<0.05)$ in the GTW1E2 group followed by the GTW1E1 group. Feed intake was not affected $(p>0.05)$ by the GTW amount but by enzyme concentration $(p<0.05)$. Layer hen fed E1 and E2 in the GTW0E1, GTW0E2, GTW1E1 and GTW1E2 groups had lower $(p<0.05)$ feed intake than layer hen fed diets without enzyme supplementation (E0) in the GTW0E0 and GTW1E0 groups. Feed conversion ratio (FCR) was significantly affected by both GTW and enzyme level. The low FCR $(\mathrm{p}<0.05)$ was present in the GTW1E2 group, followed by the GTW1E1, GTW0E1 and GTW0E2 groups.

The results are in line with previous research. The high level of green tea by-products $(4.00 \%$ and $6.00 \%)$ promoted egg production (Yang et al., 2003). AI-Harthi (2004) and Abdo et al. (2010) also found that the addition of green tea or its aqueous extract resulted in improvement in egg production, egg mass and feed conversion values. Yang et al. (2003) reported that feed conversion in broilers fed with green tea by products were slightly lower in the diets supplemented with $1 \%$ and $2 \%$ of green tea by products. These results are probably due to the availability of nutritive values of GTW like tannin, an anti-nutritional factor in plant materials which can bind proteins precipitate proteins and inhibit bacterial growth ( Sakanaka et al., 2000), carotene and antioxidative properties. Condensed tannin is mainly polymerized products of flavan 3-ols (catechin) (Jansman ,1993). According to Karori et al. (2007) the chemical compositions of green tea are included a complex of polyphenols, alkaloid, amino acids, carbohydrates, protein, chlorophyll, volatile compound, minerals and other unidentified compounds. The major tea polyphenol compound is flavan -3-ols called catechins. The total catechins in green tea are $13.6 \mathrm{~g} / 100 \mathrm{~g}$ dry weight. They are good antioxi- dant agents of free radical scavenger for promotion of health and prevention of diseases in humans and animals (Vuong et al, 2011; Yamamoto et al, 1997). Antioxidants or free radical scavengers help prevent and repair the cell damage caused by the free radicals. These promote animal health, resulting in layer performance. The high egg production and egg mass were observed in the GTW1E1 and GTW1E2 groups due to absorption of the polyphenol compound contents of GTW through the intestinal walls, which positively affected the digestive function, egg formation process and feed efficiency of hens.

Enzyme supplementation had an effect on feed intake and feed conversion. Similar results were witnessed by Geraert et al. (2003) who founded that the supplementation of xylanase, beta-glucananase and cellulase in layer diets based on wheat, barley or maize improved the digestibility of energy, protein and lipid. These results are reflected in improvement in feed conversion. Adding both glucanase and xylanase to maize/soy-based diets has been shown to improve feed conversion and ileal nutrition digestibility (Cowieson et al., 2010). In addition, Viveros et al. (1994) and Jaroni et al. (1999) found that adding enzyme in animal diets improved intestinal morphology and integrity, which resulted in enhanced digestion and absorption of dietary components. However, some previous studies founded that supplementation of exogenous plant cell walls, glucanase and xylanase, showed no effect on improving nutritive values of alfalfa-containing diets in layer hens. Such supplementation could not significantly improve layer performance (Mourao et al., 2006). Similar results were also witnessed this study. Supplementation of phytase, xylanase and cellulase exhibited a little improvement on layer production performance because nowadays, some enzymes especially fibrolytic enzymes such as xylanase and cellulase including phytase are already added in some commercial diets. Moreover, the physiology of layer hens' digestive tracts is better at digesting fibers than those of broilers, which in turn will absorb more nutrients. Hence, the concentration of enzyme supplementation in diets needs to be taken into consideration. It is clear that as for the GTW supplementation groups in this study, fibrolytic enzymes including xylanase, cellulase and phytase could digest fibers and phytate, release more nutrients of sugar from fibers, release proteins, amino acids and minerals from phytate (See Ta- 
ble 2). Therefore, animals receive more energy and nutrients, which is demonstrated in the decreasing of layer feed intake in the GTW0E1, GTW0E2, GTW1E1 groups and especially in the GTW1E2 group that saw a lower FCR of layers.

\section{Egg Quality}

Egg quality is presented in Table 4. The results of enzyme and GTW supplementation showed a significant effect $(p<0.05)$ on egg quality. Supplemental enzymes and GTW significantly $(p<0.05)$ improved Haugh unit (index of egg internal quality), specific gravities of eggs and the antioxidative property of eggs (i.e. reducing lipid oxidation). Haugh unit was significantly high in all GTW1 groups especially the GTW1E2 group and a high dosage of enzyme E2 presented a rather high Haugh unit than E1 and E0 groups. The specific gravity was low $(p<0.05)$ in GTW1 group, with the lowest level $(p<0.05)$ witnessed in GTW1E2 group. An antioxidant property of eggs was investigated in term of TBAs value (lipid oxidation value). TBAs value was significantly affected $(\mathrm{p}<0.05)$ by enzyme. TBAs value was lowest in the GTW1E2 group and the highest TBAs value was found in control (GTW0E0) group.

Supplementation of GTW in the diet significantly increased $(p<0.05)$ Haugh unit. It was also found that lipid oxidation in term of thiobarbituric acid reactive substance value (TBAs) decreased in the GTW1E2 group. Generally, nutrients in layer diets do not appear to have any effects on Haugh unit (Naber, 1979), but certain natural antioxidants such as vitamin $C$, vitamin $E$ and selenium benefit albumen quality in term of the antioxidant property (Keshavarz, 1996; Sahin et al., 2003).

Green tea waste in the present experiment contained $0.01 \%$ of tannin, $203.40 \mathrm{mg} / \mathrm{kg}$ of carotenoid and $56.56 \%$ of DPPH scavenging. These results are in line with those in Varilek et al. (2001) and also Wilhelm and Helmut (2003). They reported that the beneficial effects of green tea came from its contents of catechins, flavonoid, phenolic extracts and carotenoids. The active substances of green tea can act as a reducing agents, hydrogen donator, and superoxide radical scavengers. Carotenoids are high antioxidants for scavenging singlet oxygen molecules and peroxyl radicals. This mechanism could be a possible mechanism for increasing Haugh unit due to the antioxidant effect from tea polyphenols. This finding is in accordance with Abdo et al. (2010), who found that adding green tea powder in laying hen dies for 1 to $3 \%$ or green tea extracts at 0.5 to $1.5 \mathrm{~L} / 100 \mathrm{~kg}$ can reduced thiobarbituric acid values of egg yolk, implying its potential effect on egg quality parameters, especially during storage. Similar results are witnessed in AlHarthi (2014) who found that supplementing green tea for $1 \mathrm{~g}$ per 1 $\mathrm{kg}$ in layer diets can improve Haugh unit score $(3.5 \%)$ of stored eggs when compared to the control group and green tea supplemented with vitamin $\mathrm{E}$ resulted in an improvement in Haugh unit score $(2.4 \%)$ of fresh eggs and Haugh unit score $(10.9 \%)$ of stored eggs. It is possible that transfer of the antioxidant constituents of GTW through feeding might inhibit the chain reaction involved in oxidation of the consumed lipids, thus decreasing the oxidation products transferred into eggs and reducing TBAs value. Egg specific gravity (indirect measurements of shell strength) was lowest in the GTW1E2 group $(p<0.05)$, may lower nutrient availability, especially of calcium and phosphorus through the intestines during shell formation due to the use of GTW containing tannin. Tannin is a group of polyphenols which can bind protein then reduced digestibility of nutrients (Mueller-Harvey, 2006; Bravo, 1998; Jansman, 1993). Tannin also has a bacterial inhibition property (Sakanaka et al., 2000). However, phytase supplementation has been shown to improve eggshell quality, and the effect of phytase supplementation depends on the levels of calcium and nonphytate phosphorus in the diet (Hatten et al. ,2001; Jamroz et al., 2003; Lim et al., 2003).

\section{CONCLUSION}

Supplementation of $1 \%$ GTW, 24,000 FAXU xylanase, 100 ECU cellulase and 1,000 FTU phytase (GTW1E1) in layer diet is recommended to improve egg performance as it increased egg production and egg mass. A high dosage of $1 \%$ GTW supplemented with 48,000 FAXU xylanase, 200 ECU cellulose, and 2,000 FTU phytase (GTW1E2) in the layer diet is recommended for enhancing layer performance in terms of improving feed conversion by reducing feed intake, feed cost $/ \mathrm{kg}$ of eggs, TBAs value, and increasing Haugh unit. 


\section{ACKNOWLEDGMENTS}

The researchers would like to thank $\mathrm{AB}$ vista Asia Ltd. (Singapore) for kindly providing the enzymes and analyzing the enzyme contents in the diets for this research. Our special thanks also go to the Valaya Alongkorn Rajabhat University under The Royal Patronage for financially supporting this research.

\section{REFERENCES}

AB vista . 2018. Analysis method for Quantum Blue in Feed (wet chemistry method), Econase XT and Vista Pre-T (wet chemistry method) . AB vista Asia Ltd., Singapore.

AOAC. 1990. Official Method of Analysis of Association of Official Analytical Chemists. AOAC, Washington, DC.

Abdo, Z.M.A., R.A. Hassan, A.E. Amal and A.H. Shahinaz. 2010. Effect of adding green tea and its aqueous extract as natural antioxidants to laying hen diet on productive, reproductive performance and egg quality during storage and its content of cholesterol. Egypt. Poult. Sci. 30:11211149.

Al-Harthi, M.A. 2004. Responses of laying hens to different levels of amoxicillin, hot pepper or green tea and their effects on productive performance, egg quality and chemical composition of yolk and blood plasma constituents. Egypt. Poult. Sci. 24:845-868.

Al- Harthi, M.A. 2014. The effect of natural and synthetic antioxidants on performance, egg quality and blood constituents of laying hen grown under high ambient temperature. Ital. J. Anim. Sci. 3:444-447.

Bedford, M.R. 2000. Exogenous enzyme in monogastric nutrient - their current value and future benefits. Anim. Feed Sci. Technol. 86:1-13.

Bisswanger, H. 2011. Practical Enzymology. $2^{\text {th }}$ ed. Wiley-VCH Verlag \& Co. KGaA, Boschstr. Weinheim, Germany. 360 p.

Botsoglou, N. A., D. J. Fletouris, G. E. Papageorgiou, V. N. Vassilopoulos, A. J. Mantis and A. G. Trakatellis. 1994. Rapid,sensitive and specific Thiobarbituric acid method for measuring lipid oxidation in animal tissue, food and feedstuff samples. J. Agri. Food Chem. 42:1931-1937.
Bravo, L. 1998. Polyphenols: Chemistry, dietary sources, metabolism, and nutritional significant. Nutr. Res. Rev. 56:317-333.

Bunyapraphatsara, N and P. Sornlek. 2007. Preparation of tea marc extract and feed additive. Final report. Thailand Science Research and Innovation.

Cherian, G., F. W. Wolfe and J. S. Sim. 1996. Dietary oils with added tocopherols effects on egg or tissue tocopherols fatty acids and oxidative stability. Poult. Sci. 75:423431.

Cowieson, A.J., M.R. Bedford and V. Ravindran. 2010. Interaction between xylanase and glucanase in maize-soy-based diets for broilers. Brit. Poul. Sci. 51:246-257.

FAO, IAEA. 2000. Quantification of tannins in tree foliage, FAO/IAEA Working Document, Vienna. $31 \mathrm{p}$.

Foss, P., R. R. L. Guillard and S. Liaaen - Jensen. 1984. Prasinoxanthin chemosystematic marker for algae. Phytochemistry. 23: 1629-1633.

Geraert, P.A. and P. Dalibard. 2003. Enzyme in layer diet and opportunity. World Poult. 19(3):3-4.

Hatten, L.F., D.R. Ingram and S.T. Pittman. 2001. Effect of phytase on production parameters and nutrient availability in broilers and laying hens : A review. J. Appl. Poult. Res. 10:274-278.

Jansman, AJM. 1993. Tannin in feedstuffs for simple stomached animal. Nutr. Res. Rev. 6:209-236.

Jamroz, D., J. Orda, J. Skorupinska, A. Wi1iczkiewicz, T. Wertelecki, R. Zylka and A.M. Klunter. 2003. Reaction of laying hens to low phosphorus diets and addition of different phytase preparations. J. Anim. and Feed Sci.. 12:95-110.2003.

Jaroni, D., S.E. Scheideler, M.M. Beck and C. Wyatt. 1999. The effect of dietary wheat middling and emzyme supplementation II: Apparent nutrient digestibility, digestive tract size, gut viscosity and gut morphology in two strain of Leghorn hens. Poult. Sci. 78:1664-1674.

Karori, S., F. Wachira, J. Wanyoko and R. Ngure. 2007. Antioxidant capacity of different types of tea products. J. Biotech. 6:2287-2296.

Keshavarz, K. 1996. The effect of different levels of vitamin $\mathrm{C}$ and cholecalciferol with adequate or marginal levels of dietary cal- 
cium on performance and eggshell quality of laying hens. Poult. Sci. 75:1227-1235.

Khattak, F.M., T.N. Pasha, Z. Hayat and A. Mahmud. 2006. Enzyme in poultry nutrition. J. Anim. PI. Sci. 16:1-7.

Ko, S.Y., I.H. Bae, S.T. Yee, S.S. Lee, D. Uuganbayar, J.I. Oh and C.J. Yang. 2008. Comparison of the effect of green tea byproduct and green tea probiotics on the growth performance, meat quality, and immune response of finishing pigs. AsianAust. J. Anim. Sci. 21: 1486-1494.

Kondo, M., K. Kita and H. Yokota 2004a. Effect of tea leaf waste of green tea, oolong tea and black tea addition on sudangrass silage quality and in vitro gas production. J. Sci. Food Agric. 84:721-727.

Kondo, M., K. Kita and H. Yokota. 2004b. Ensill green tea waste as partial replacement for soybean meal and alfalfa hay in lactating cows. Asian-Aust. J. Anim. Sci. 7:960-966.

Krueger, W.K., H. Gutierrez-Banuelos, G.E. Carstens, B.R. Mind, W.E. Pinchak, R.R. Gomez, R.C. Anderson, N.A. Krueger and T.D.A. Forbes. 2010. Effects of dietary tannin source on performance, feed efficiency, ruminal fermentation, and carcass and non-carcass traits in steers fed a highgrain diet. Anim. Feed Sci. Technol. 159:1 -9. DOI:10.1016/j.anifeedsci.2010.05.003

Li, M. and Z. Liu. 1999. Effects of tea polyphenol on pathogenic bacterial in oral and pharynx in vitro. J. Agri. Food Chem. 19: 41-55.

Lim, H.S, H. Namkung and I.K. Paik. 2003. Effects of phytase supplementation on the performance, egg quality and phosphorus excretion of laying hens fed different levels of dietary calcium and nonphytate phosphorus. Poult. Sci. 82:92-99.

Mangan, J.L. 1988. Nutritional effect tannin in animal feed. Nutri. Res. Rev. 1:209-231.

Miyazawa, T. 2000. Absorption metabolism and antioxidant effects of tea cathechin in human. J. Bio. Factors. 13: 55-59.

Mohammed, A. and Al-Harthi . 2014. The effect of natural and synthetic antioxidants on performance, egg quality and blood constituents of laying hens grown under high ambient temperature. Ital. J. Anim. Sci. 13:444-449.

Mourao, J.L., P. I. P. Ponte, J. A. M. Prates, M. S. J. Centeno, L. M. A. Ferreira, M. A. C.
Soares, and C. M. G. A. Fontes. 2006. Use of $\beta$-glucanases and $\beta$-1,4-xylanasesto supplement diets containing alfalfa and rye for laying hens. J. Appl. Poult. Res. 15:256-265.

Mueller-Harvey, I. 2006. Review unravelling the conundrum of tannins in animal nutrition and health. J. Sci. Food Agric. 86:20102037.

Naber, E. C. 1979. The effect of nutrition on the composition of eggs. Poult. Sci. 58:518528.

Onyango, E. M., M. R. Bedford and O Adeola. 2004. The yeast production system in which Escherichia coli phytase is expressed may affect growth performance, bone ash, and nutrient use in broiler chicks. Poult. Sci. 83: 421427.

Ravindran, V., P.C.H. Morel, G.G. Partridge, M. Hurby and J.S. Sands. 2006. Influence of an Escherichia coli-derived phytase on nutrient utilization in broiler starter fed diets containing verying concentration of phytic acid. Poult. Sci. 83:1588-1595.

Ravindran, V., P.H. Selle, G. Ravindran, P.C.H. Morel, A.K. Kies and W.L. Bryden. 2001. Microbial phytase improve performance, apparent metabolizable energy, and ileal amino acid digestibility of broiler fed a lysine- deficient diet. Poult. Sci. 80:338344.

Roche M, C. Dufour, N. Mora and O. Dangles. 2005. Antioxidant activity of olive phenols: mechanistic investigation and characterization of oxidation products by mass spectrometry. Org. Biomol. Chem. 3: 423430.

Sahin, N., K. Sahin and M. Onderci. 2003. Vitamin $\mathrm{E}$ and selenium supplementation to alleciate cold-stress-associated deterioration in egg quality and egg yolk mineral concentrations of Japaness quails. Biol. Trace Elem. Res.96:179-189.

Sakanaka, S., L.R. Junaja, M. Taniguchi. 2000. Antimicrobial effect of green tea polyphenol on thermophilic spore-forming bacteria. J. Biosci. Bioeng. 90:81-85.

Toh, K., H. Yokoyama, H. Noda and Y. Yuguchi. 2010. Antioxidant capacity of lignin from green tea waste. J. Food Biochem. 34:192-206.

Trompezimski, S., A. Denis, D. Schmitt and J. Viac. 2003. Comparative effects of polyphenols from green tea (EGCG) and soy- 
bean (genistein) on VEGF and IL-8 release from normal human keratinocytes stimulated with the proinflammatory cytokins TNF- $\alpha$. Arch. Dermatol. Res. 295: 112-116. DOI:10.1007/s00403-003-0402$\mathrm{y}$.

Tsubaki, S., H. Iida, M. Sakamoto and J.I. Azuma. 2008. Microwave heating of tea residue yields polysaccharides, polyphenols, and plant biopolyester. J. Agric. Food Chem. 56:11293-11299.

Varilek, G.W., F. Yang, E.Y. Lee, W.J.S. deVilliers, J. Zhong, H.S. OZ, K.F. Westberry and C.J. McClain. 2001. Green tea polyphenol extract attenuates inflammation in interleukin-2-deficient mice, a model of autoimmunity. 2001. American Society for Nutritional Sciences. J. Nutr. 131:2034-2039. DOI: 10.1093/ jn/131.7.2034.

Viveros, A., A. Brenes, M. Pizarro and M. Castano. 1994. Effect of enzyme supplementation of a diet base on barly, and autoclave treatment, on apparent digestibility, growth performance and gut morphology of broiler. Anim. Feed Sci. Technol. 48:237-251.

Vuong, Q.V, C.E Stathopoulos, M.H. Nguyen, J.B. Golding and P.D. Roach. 2011. Isolation of green tea catechins and their utilization in the food industry. Food Rev.
Int.

27:227-247.

DOI:

$10.1080 / 87559129.2011 .563397$

Wilhelm, S. and S. Helmut. 2003. Antioxidant activity of carotenoids. Mol. Aspects Med. 24:345-351.

Woyengo, T. A. and C. M. Nyachoti. 2011. Supplementation of phytase and carbohydrases to diets for poultry : Rev. Can. J. Anim. Sci. 91: 177:192. DOI: 10.4141/ CJAS10081.

Yang, C.J., I.Y. Yang, D.H. Oh, I.H. Bae, S.G. Cho, I.G. Kong, D. Uuganbayar, I.S. Nou1 and K.S. Choi. 2003a. Effect of green tea by-product on performance and body composition in broiler chicks. Asian-Aust. J. Anim. Sci. 16:867-872. DOI: 10.5713/ ajas.2003.867.

Yang, C.J., Y.C. Jung and D. Uuganbayar. 2003b. Effect of feeding diets containing green tea by-products on laying performance and egg quality in hens. Kor. J. Poult. Sci. 30:183-189.

Yamamoto, T., L.R. Juneja, D.C. Chu and M. Kim. 1997. Chemistry and Application of Green Tea. CRC press, Florida, USA. $186 \mathrm{p}$.

Yu, B., Y.C. Jana., T.K. Chungb, T.T. Leea, P.W.S. Chioua. 2004. Exogenous phytase activity in the gastrointestinal tract of broiler chickens. Anim. Feed Sci. Tech. 117:295-303. 